\title{
A field trial to assess action thresholds for management of Bactericera cockerelli in main crop processing potatoes at Pukekohe
}

\author{
G.P. Walker ${ }^{1}$, F.H. MacDonald ${ }^{1}$, A.J. Puketapu ${ }^{2}$, P.J. Wright ${ }^{2}$, P.G. Connolly ${ }^{1}$ and J.A.D. \\ Anderson $^{2}$ \\ ${ }^{1}$ The New Zealand Institute for PlantE Food Research Limited, Private Bag 92169, \\ Victoria Street West, Auckland 1142, New Zealand \\ ${ }^{2}$ The New Zealand Institute for Plant \& Food Research Limited, Cronin Road, RD1, \\ Pukekohe, New Zealand \\ Corresponding author: graham.walker@plantandfood.co.nz
}

\begin{abstract}
A main crop summer potato trial at Pukekohe assessed the damage caused by Bactericera cockerelli, tomato potato psyllid (TPP), and investigated the use of action spray thresholds. Five treatments were used: in-furrow insecticide and weekly blocks of foliar sprays; in-furrow insecticide and one of three different threshold-based foliar spray programmes; and no insecticides. The threshold-based spray programmes used either the number of TPP nymphs per middle leaf or the mean number of TPP adults per yellow sticky trap per week, plus different mode-of-action insecticide rotations. Three treatments resulted in acceptable yield and specific gravity, and a low incidence of zebra chip disease (ZC). These were the weekly treatment and two spray programmes based on a threshold of $>3$ TPP adults per trap per week where insecticide applications were reduced by $50 \%$ compared to the weekly applications.
\end{abstract}

Keywords tomato-potato psyllid, Bactericera cockerelli, potatoes, insecticide trials, action thresholds.

\section{INTRODUCTION}

The tomato-potato psyllid (TPP), Bactericera cockerelli (Sulc) (Hemiptera: Triozidae), and its associated bacterial pathogen, Candidatus Liberibacter solanacearum (Lso), cause zebra chip (ZC) disorder in potato (Solanum tuberosum L.). The psyllid is estimated to have cost the potato industry around NZ\$60 M since it was first found and that figure is expected to grow (Anonymous 2013). Most of this cost is due to crop impacts (yield and quality) and control costs (additional insecticides and spray applications), with past experience in New Zealand suggesting that the only effective way to minimise the impacts of TPP and ZC is the careful application of well- timed agrichemical sprays (Anonymous 2009). Insecticides may not be required for growing healthy early-crop potatoes at Pukekohe because flights and numbers of TPP invading these crops have been below an economic injury level (EIL) (Walker et al. 2012). However, increases in both trap catches and crop infestations in late December and early January indicate a rapid increase in risks of damage to summer crops (the main crop for processing) by TPP and ZC from that time on (Walker et al. 2011). In an attempt to reduce reliance on calendar applications of insecticides to main crop potatoes, a MAF Sustainable Farming Fund project (Contract no. 
09/143) funded 3 years of trials at Pukekohe to test different insecticides and action thresholds and their impact on TPP populations and damage to main crop processing potato crops (Walker \& Dohmen-Vereijssen 2012). Treatments in year 1 and year 2 of these trials tested a nominal action threshold based on levels of infestation of TPP nymphs on plants. However, levels of ZC were unacceptable in all reduced spray treatments in both years (Walker \& Dohmen-Vereijssen 2012; Walker et al. 2012; G.P. Walker, unpublished data). Buchman et al. (2011) reported that adult TPP are highly efficient vectors of Lso (the causal agent of ZC) and that nymphs are less efficient than adults at transmitting this bacterium. Therefore, in year three of the SFF trials, action thresholds based on monitoring of sticky trap catches of adult TPP were incorporated, and these treatments were compared with previously tested treatments. This paper reports on the results of this main crop trial in 2011/12 and progress in developing a reduced spray programme for main crop potatoes grown for processing at Pukekohe.

\section{MATERIALS AND METHODS}

\section{Crop management}

The trial was conducted in summer 2011/12 at the Plant \& Food Research Pukekohe Research Station ( $174^{\circ} 55^{\prime}$ E, $\left.37^{\circ} 10^{\prime} \mathrm{S}\right)$. Potato seed tubers 'Moonlight' (certified PT $2^{\text {nd }}$ generation 50-100 g seed) were planted on 31 October and 1 November at an inter-row spacing of $300 \mathrm{~mm}$ and a depth of ca $250 \mathrm{~mm}$. The soil type is a Patumahoe mottled clay loam and has a $\mathrm{pH}$ of 6.1. Soil fertility was amended with an application of $2.5 \mathrm{t} /$ ha "Potato Mix" (N:P:K=6:6:6) at planting. Metribuzin and linuron were applied prior to crop emergence for weed control, and mancozeb was applied for blight control at recommended rates at 7-10 day intervals throughout the growing season.

\section{Trial layout}

The trial utilised a fully randomised block design of four treatments with four replicates, plus a control treatment. Plots were $12 \mathrm{~m}$ long and $6.2 \mathrm{~m}$ wide, incorporating eight rows of potatoes spaced $750 \mathrm{~mm}$ apart. Each plot comprised approximately 320 seed tubers and plots were separated by non-planted buffers, $3.1 \mathrm{~m}$ wide (left fallow). The untreated control treatment was located remotely from this area to reduce the high pest pressure of untreated plots immediately adjacent to treated plots (G.P. Walker, unpublished data). This remote planting was $30 \times 40 \mathrm{~m}$ located north of the main trial site and divided visually into four quadrants for monitoring.

\section{Sticky traps and thresholds}

At plant emergence, double-sided yellow sticky traps, measuring $100 \times 250 \mathrm{~mm}$ (Biobest, Belgium), were placed in the middle of each of the four 'standard sequence of insecticides' trap threshold plots and also in each of the four quarters of the untreated remote planting. Each trap was attached just above canopy height and secured to a metal stake. The traps were replaced weekly or twice weekly and stored in plastic pockets to allow identification and counting of TPP and other psyllid species. Sticky traps were maintained from 23 November 2011 to 13 March 2012 and assessed weekly until 14 December and thereafter twice weekly. The numbers of TPP trapped were adjusted to the number of TPP per trap per week for spray decisions based on trap catches.

\section{Plant sampling and thresholds}

Initially eight plants from each of the four plots in each treatment (32 plants per treatment) were assessed weekly in situ by recording all life stages of all relevant insect species present on the whole plant. After 3 weeks of whole plant assessments, sampling changed to 25 middle leaves per plot, comprising two middle leaves from separate stems from 12 plants, plus one more middle leaf per plot; giving a total of 100 middle leaves per treatment. Previous research to determine a practical, cost-efficient method of subsampling potato plants has demonstrated that assessing a middle leaf is a reliable indicator of the actual infestations on a whole plant (Walker et al. 2013). Middle leaf counts are now recommended by Potatoes NZ (Anononymous 2012) and were used for the action threshold based on number of TPP nymphs per middle leaf. For the trap thresholds, a nominal threshold of $>3$ TPP per 
trap per week was used to initiate a foliar-applied insecticide treatment.

\section{Treatments}

Thiamethoxam 250WSG (Actara ${ }^{\circledR}$ ) was applied to all treatments except the untreated control by backpack sprayer (single nozzle) at planting as an in-furrow spray over the tubers at $4 \mathrm{~g} / 100 \mathrm{~m}$ row applied in 50-100 litres water/ha. The foliar insecticides (Table 1) were applied with a tractormounted plot sprayer using hollow-cone, nondrip nozzles at a water rate of 500 litres/ha at a pressure of 8 bar (120 psi). Foliar applications were made to the 'Weekly' treatment from $60 \%$ emergence of plants, starting on 29 November 2011. The different mode-of-action insecticides in each treatment were each applied in a sequence of blocks as in Table 1.

\section{Tuber yields and specific gravity}

Senescing plant tops were sprayed off on 20 March 2012. The trial was machine harvested on 26 and 27 March, and tuber yields and size-grades were assessed. For tuber yield and quality assessments, the two middle rows from each plot were dug and a $5 \mathrm{~m}$ length defined in the middle of each plot. All tubers within this area were graded visually into 'marketable' (undamaged and >60 g (larger than a golf ball)) or 'reject' (<60 g) categories. To ensure that damage was restricted to impacts from TPP and ZC, tubers that would normally be rejected because of greening or damage by potato tuber moth (PTM), Phthorimaea operculella (Zeller) (Lepidoptera: Gelechiidae) were not added to the reject category. The weights of the two grades were recorded. A representative subsample of at least 30 tubers (approximately one tuber chosen from each plant) was also picked from this area in each plot for assessment of specific gravity and ZC. Tuber specific gravity was determined on 27 March by calculating the difference in weight of all marketable tubers in air and in water.

\section{Cooking tests for 'zebra chip'}

On 28 March, 30 of these same tubers were randomly selected for cooking tests ('crisping')

Table 1 Insecticide treatments for control of tomato-potato psyllid (TPP) in a main crop potato trial at Pukekohe Research Station, 2011/2012. Thiamethoxam (Actara ${ }^{\circledR}$ 250WSG) in furrow was used at planting in every treatment except untreated.

\begin{tabular}{|c|c|c|}
\hline Treatment name & Action threshold & Spray programme sequence \\
\hline $\begin{array}{l}\text { Weekly, standard } \\
\text { sequence of } \\
\text { insecticides }\end{array}$ & $\begin{array}{l}\text { Weekly foliar } \\
\text { applications from } \\
60 \% \text { plant emergence }\end{array}$ & 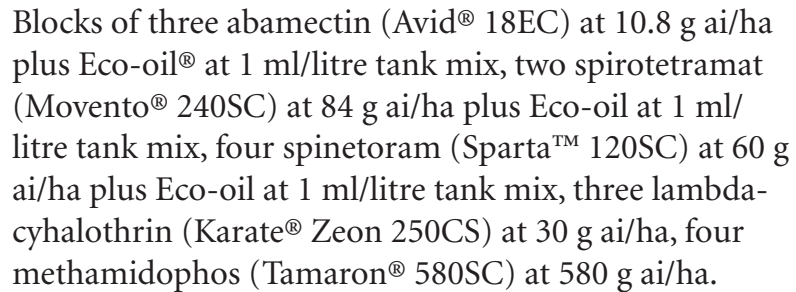 \\
\hline
\end{tabular}

\begin{tabular}{lll}
\hline $\begin{array}{l}\text { Trap threshold } \\
\text { knockdown } \\
\text { insecticides })\end{array}$ & $\begin{array}{l}>3 \text { TPP adults per } \\
\text { trap per week }\end{array}$ & $\begin{array}{l}\text { Blocks of three abamectin, two thiacloprid at } 75 \mathrm{~g} \text { ai/ha } \\
\text { and deltamethrin at } 10 \mathrm{~g} \text { ai/ha }\left(\text { Proteus }{ }^{\circledR}\right) \text { plus Eco-oil at } \\
1 \mathrm{ml} / \text { litre tank mix, three methamidophos. }\end{array}$ \\
\hline $\begin{array}{l}\text { Trap threshold } \\
\text { standard } \\
\text { sequence) }\end{array}$ & $\begin{array}{l}>3 \text { TPP adults per } \\
\text { trap per week }\end{array}$ & $\begin{array}{l}\text { Blocks of three abamectin, two spirotetramat, three } \\
\text { spinetoram. }\end{array}$ \\
$\begin{array}{l}\text { TPP nymph } \\
\text { threshold, } \\
\text { then standard } \\
\text { sequence }\end{array}$ & $\begin{array}{l}\text { 0.1 TPP nymph per } \\
\text { middle leaf }\end{array}$ & Blocks of three abamectin, two spirotetramat. \\
\hline \begin{tabular}{l} 
Untreated \\
\hline
\end{tabular} & \\
\hline
\end{tabular}


to determine the incidence of ZC. A single crisp slice of around $2 \mathrm{~mm}$ thickness was cut from the centre of each tuber with a stainless steel mandoline slicer and crisps were then fried in canola oil in batches of 10 for 3 to $3.5 \mathrm{~min}$ at $180^{\circ} \mathrm{C}$. Each individual crisp was then assessed on a $0-9$ scale for symptoms of ZC where $0=$ no browning and $9=$ dark brown (Anderson et al. 2013). The percentage of crisps in each scale was assessed for each treatment.

\section{Statistical analysis}

The bias introduced by using remote control blocks is assumed to be less than what would occur if highly infested blocks were located adjacent to treatments, since the aim is to ascertain the effect of a treatment that is to be generalised to a whole field. The means of weekly sticky trap catches were calculated, but differences between counts due to the position of the four traps in the different treatments were not assessed. Also, the numbers of TPP located on the middle leaves were not analysed. For the tuber data, least significant differences (LSD) were calculated for each variable of interest (marketable weight, specific gravity and ZC symptoms) using an analysis of variance using $\mathrm{R}$ version 2.15.2. To make a better approximation to the normal distribution, percentages of ZC were analysed on the angular scale and the means back-transformed. Where the significance of the difference was border-line, the Tukey's adjustment for multiple comparisons was made before concluding whether the difference was sufficiently large to allow for the fact that there are six possible pairs of comparisons. Groupings were made using the multicompView $\mathrm{R}$ package (Graves et al. 2012).

\section{RESULTS}

\section{Sticky traps and thresholds}

Figure 1 shows the trends in mean weekly trap catches of TPP captured on the four sticky traps in the untreated area and in the trap threshold plots. TPP adult catches were $\leq 1$ per trap through until 20 December 2011 when the weekly count was 2.8 per trap in the threshold plots. A week later (27 December) the average was 9.8 and the first decision to spray was made. However, insecticides were not applied until 2 January 2012 because of a period of consistent heavy rain when $86 \mathrm{~mm}$ of rain was recorded over 3 days. The weekly average catch was 3.2 on 3 January and the decision was made to not spray. From that week onwards weekly average catches were $>8$ per trap until 28 February (Figure 1), so that eight applications were made in the trap threshold plots. No insecticides were applied after 21 February and weekly trap catches were 3.1 and 2.2 per trap until the last week of monitoring (at crop harvest stage) when trap catches were six per trap per week (Figure 1).
Figure 1 Mean number of Bactericera cockerelli (tomato potato psyllid; TPP) adults captured per sticky trap per week and TPP nymphs per middle leaf in untreated and threshold plots of potatoes at Pukekohe from 29 November 2011 to 13 March 2012.

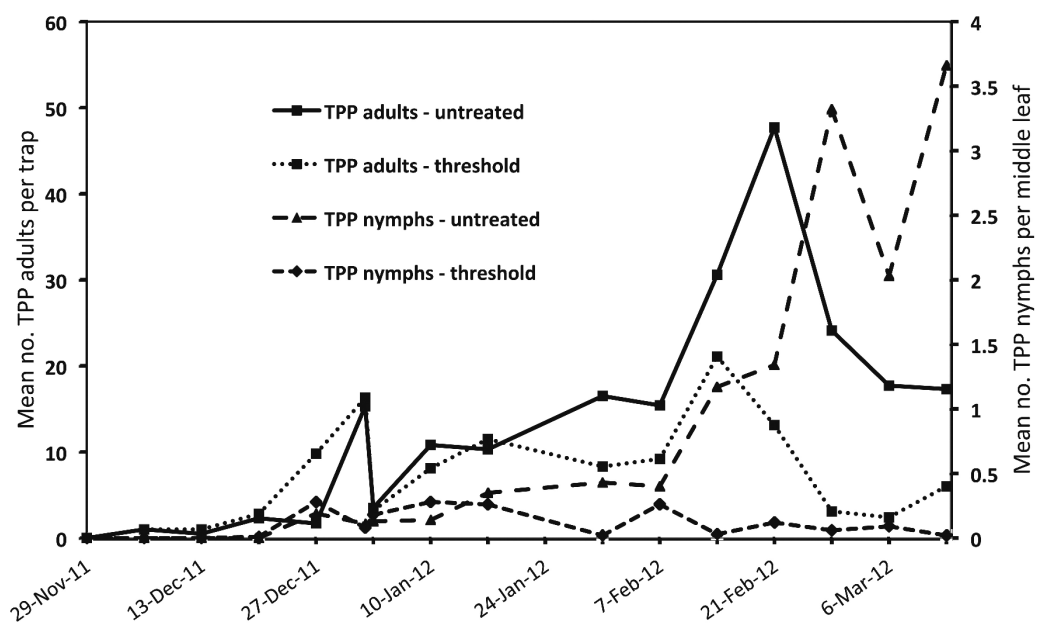


Table 2 Summary of number of foliar-applied insecticide treatments, average marketable tuber yields and reject weights $\left(\mathrm{kg} / 10 \mathrm{~m}^{2}\right)$, specific gravity and zebra chip (ZC) symptoms (\%) of harvested potatoes following different spray regimes in a main crop summer trial at Pukekohe Research Station during 2011/2012.

\begin{tabular}{lccccc}
\hline & $\begin{array}{c}\text { No. } \\
\text { Treatment }\end{array}$ & $\begin{array}{c}\text { Marketable } \\
\text { tuber yield }\end{array}$ & Reject weights & Specific gravity & ZC symptoms \\
\hline $\begin{array}{l}\text { Weekly } \\
\text { Trap threshold }\end{array}$ & 8 & $59.22 \mathrm{a}$ & 0.40 & $1.0775 \mathrm{a}$ & $0 \mathrm{a}$ \\
$\begin{array}{l}\text { (knockdown) } \\
\begin{array}{l}\text { Trap threshold } \\
\text { (standard) }\end{array}\end{array}$ & $59.16 \mathrm{a}$ & 0.39 & $1.0746 \mathrm{a}$ & $2.26 \mathrm{a}$ \\
$\begin{array}{l}\text { Nymph threshold } \\
\text { Untreated }\end{array}$ & 5 & $60.07 \mathrm{a}$ & 0.50 & $1.0769 \mathrm{a}$ & $1.23^{1} \mathrm{a}$ \\
LSD & 0 & $53.77 \mathrm{a}$ & 0.64 & $1.0736 \mathrm{a}$ & $7.56 \mathrm{a}$ \\
\hline
\end{tabular}

${ }^{1} 1$ tuber out of 120 with $>2$ ZC score.

${ }^{2}$ LSD on transformed scale (since it cannot be back-transformed meaningfully).

\section{Plant sampling and thresholds}

Figure 1 also shows the trends in mean numbers of TPP nymphs per middle leaf in the untreated area and in the trap threshold plots. TPP nymphs were not located in any treatments until 20 December. Nymph numbers reached 0.28 per middle leaf on 27 December when the first decision to apply a foliar insecticide was made. Heavy rain over this period and a total of 0.18 per middle leaf led to a decision not to spray the following week. The nymph threshold was exceeded the following 2 weeks with 0.28 and 0.26 TPP nymphs per middle leaf leading to the application of the second and third abamectin application. The nymph threshold was exceeded on 7 and 21 February leading to two applications of spirotetramat, with five insecticides applied in total over the trial period using the nymph threshold.

\section{Treatments, tuber yields, specific gravity and cooking tests for zebra chip}

A summary of the number of foliar treatments, average tuber weights, specific gravity and ZC scores for the five treatments is presented in Table 2. The weekly (16 foliar sprays) and the two trap threshold treatments (eight foliar sprays) all gave acceptable results for marketable weights and specific gravity, with ZC symptoms being
$0,1.23$ and $2.26 \%$ for weekly, standard and the knockdown trap threshold respectively. For the standard threshold just one tuber out of the 120 tested had unacceptable ZC symptoms (being $>2$ on the ZC scale; Anderson et al. 2013). An artefact of fitting low incidence data on the transformed scale to the ANOVA model is that the fitted mean is higher than that observed $(0.83 \% \mathrm{ZC})$. More precise estimates would require impracticably large sample sizes.

The use of the TPP nymph threshold led to only five applications of foliar sprays but marketable weights were reduced and ZC symptoms were unacceptable $(7 \%)$, while the untreated plots gave poor results for marketable weights, specific gravity and 34\% ZC (Table 2). Reject tuber weights were not significantly different.

\section{DISCUSSION}

Previous trials testing reduced spray programmes on early crop potatoes reported that flights and numbers of TPP invading these potato crops may be below an EIL (Walker et al. 2012; Cameron et al. 2009). Walker et al. (2012) concluded from 3 years of trials that low trap catches $(<3$ TPP adults per trap) may indicate that invading populations are below an economic threshold, so that this number (three per trap per week) may be used as a trigger for foliage applications. In this 
current study there was no intervention with an insecticide spray until the trap catches increased markedly above three per trap. This is because historical data indicate that the economic injury level may be about or slightly above this threshold, and it is known that trap catches increase rapidly from about late December onwards (Walker et al. 2011; Walker \& Dohmen-Vereijssen 2012; G.P. Walker, unpublished data). In fact, trap catches were above eight per trap before an insecticide was applied. However, whether the resulting low ZC level reported here (Table 2) for the TPP trapping threshold would be commercially viable is difficult to ascertain from the present study. Knowledge of the levels of Lso infection in invading TPP populations, combined with economic action thresholds, will help determine whether populations of TPP warrant control or not (Butler \& Trumble 2012). More research is required to better define the economic action threshold based on sticky trap catches.

The action threshold based on plant infestations by TPP nymphs was not useful, resulting in excess $\mathrm{ZC}$ damage in this treatment in the current study (Table 2) and from previous research (Walker \& Dohmen-Vereijssen 2012; G.P. Walker, unpublished data). However, the trap catch threshold tested gave promising results that deserve further investigation. In this trial, heavy rainfall in December and cooler conditions over January and February appeared to affect all insect populations, with TPP infestations remaining low until later than in the previous 2 years (Walker 2011; Walker \& DohmenVereijssen 2012; G.P. Walker, unpublished data). The TPP generations were not delayed, but the first damaging flight observed in the current study was greatly reduced compared with the previous 2 years, with peaks in trap catches in late January reaching only 19 TPP per trap in this trial compared with 119 and 67 in 2010 and 2011, most likely due to very wet weather (and heavy rainfall) in late December 2011.

Early in this trial the most common insects located on plants were brown lacewing (Micromus tasmaniae (Walker) (Neuroptera: Hemerobiidae)) eggs, larvae and adults. This predatory insect appeared to control aphids and any TPP infestations early in the trial (G.P. Walker, unpublished data). These data are similar to results reported by Walker et al. (2011) from monitoring untreated potatoes. Small hoverfly (Melanostoma fasciatum (Macquart) (Diptera: Syrphidae) was not recorded in the trial until late November, with numbers increasing at the end of the trial (G.P. Walker, unpublished data). These predators are understood to be important in controlling foliage-dwelling pests on potato plants (Walker et al. 2011; G.P. Walker, unpublished data), but their role in controlling TPP adults flying into crops and therefore subsequent infection by Lso is largely unknown.

Results from this study indicate that there is potential for a reduced spray programme on main crop processing potatoes based on monitoring the flights of TPP using yellow sticky traps. With this strategy, spraying would be initiated in response to increases in trap catches and utilise a rotation of blocks of effective insecticides with different modes-of-action as part of an insecticide resistance management strategy (Anonymous 2012). Using this threshold, the number of insecticide applications was reduced by $50 \%$, with $1.2 \%$ ZC when using the 'standard' sequence of insecticides compared with $2.3 \%$ ZC using knockdown insecticides. The challenges ahead are to better define these economic injury levels and relate them to crop monitoring tools, such as sticky traps and plant subsampling systems, to minimise the use of insecticides while keeping ZC damage at a commercially-acceptable level.

\section{ACKNOWLEDGEMENTS}

We thank Robin Gardner-Gee and Mo Jeram for support during this trial. We also thank Melanie Davidson and Melanie Walker for useful comments on a draft manuscript. Funding for this project was provided by the MAF Sustainable Farming Fund Contract no. 09/143, the Ministry of Business, Innovation and Employment (previously Ministry of Science and Innovation) Contract number no. C06X0811 and Plant \& Food Research Core funding. 


\section{REFERENCES}

Anderson JAD, Walker GP, Alspach PA, Jeram M, Wright PJ. 2013. Assessment of susceptibility to zebra chip and Bactericera cockerelli of selected potato cultivars under different insecticide regimes in New Zealand. American Journal of Potato Research 90 (1): 58-65.

Anonymous 2009. Potato psyllid control. http://www.potatoesnz.co.nz/users/Image/ Graphics/PDFS/Psyllid_November09fact_ sheets_-_control_lr.pdf (accessed 21 March 2013).

Anonymous 2012. Tomato Potato Psyllid Control. Wall chart.Version 1. November 2012. Potatoes NZ, Wellington, New Zealand.

Anonymous 2013. http://www.potatoesnz. co.nz/Overview/What-we-are-working-on/ Investing-in-the-fight.htm (accessed 21 March 2013).

Buchman JL, Sengoda VG, Munyaneza JE 2011. Vector transmission efficacy of Liberibacter by Bactericera cockerelli (Hemiptera: Triozidae) in zebra chip potato disease: effects of psyllid life stage and inoculation access period. Journal of Economic Entomology 104 (5): 1486-1495.

Butler CD, Trumble JT 2012. Spatial dispersion and binomial sequential sampling for the potato psyllid (Hemiptera: Triozidae) on potato. Pest Management Science 68: 865-869.

Cameron PJ, Surrey MR, Wigley PJ, Anderson JAD, Hartnett DE, Wallace AR 2009. Seasonality of Bactericera cockerelli in potatoes (Solanum tuberosum) in South Auckland, New Zealand. New Zealand Journal of Crop and Horticultural Science 37: 295-301.
Graves S, Piepho HP, Selzer L, Dorai-Jai S 2012. MultcompView: Visualisations of Paired Comparisons. R package version 0.1-5. http:// CRAN.R-project.org/package $=$ multcompView (accessed 16 May 2013).

Walker G, Dohmen-Vereijssen J 2012. Tomatopotato psyllid insecticide trials (20092012) in SFF 09/143 (Sustainable Psyllid Management). Plant \& Food Research Client Report No. 48593 prepared for Potatoes NZ. Plant \& Food Research, Auckland, New Zealand.

Walker GP, MacDonald FH, Larsen NJ, Wallace AR 2011. Monitoring of tomato-potato psyllid and associated insects in unsprayed potatoes in New Zealand. New Zealand Plant Protection 64: 269-275.

Walker GP, MacDonald FH, Larsen NJ, Wallace AR 2012. A field trial to assess damage by Bactericera cockerelli to early potatoes at Pukekohe. New Zealand Plant Protection 65: 148-154.

Walker GP, MacDonald FH, Larsen NJ, Wright PJ, Wallace AR 2013. Sub-sampling plants to monitor tomato-potato psyllid (Bactericera cockerelli) and associated insect predators in potato crops. New Zealand Plant Protection 66: 341-348. 